GRASAS Y ACEITES 72 (2)

April-June 2021, e406

ISSN-L: 0017-3495

https://doi.org/10.3989/gya.1142192

\title{
Effects of different baking techniques on the quality of walnut and its oil
}

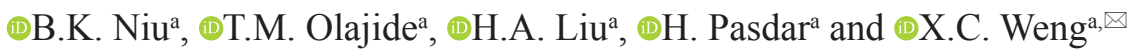 \\ aSchool of Life Sciences, Shanghai University 333, Nanchen Road, Shanghai, 200444, China \\ ${ }^{\circledR}$ Corresponding author: wxch@staff.shu.edu.cn
}

Submitted: 22 November 2019; Accepted: 29 April 2020; Published online: 07 June 2021

SUMMARY: The baking conditions of walnut kernels were optimized based on different cultivars and baking methods. The influence of the different baking techniques on the chemical properties of walnut oils was determined. The results showed that acid value, peroxide value and induction period (IP) all significantly increased in the baked samples compared to the unbaked ones. The highest increase in IP was from 6 to $17 \mathrm{~h}$ indicating that baking can improve the oxidative stability of walnut oils and prolong their shelf-life. Several aroma components increased after baking. However, among the different baking conditions, the strongest aroma in walnut oil was observed after baking was done for 20 min with sucrose $(107 \%)$ at $153^{\circ} \mathrm{C}$. Nevertheless, baking had little effect on the fatty acid composition of walnuts.

KEYWORDS: Aroma components; Baking technique; Chemical composition; Oil quality; Walnut oil

RESUMEN: Efecto de diferentes técnicas de horneado en la calidad de las nueces y su aceite. Las condiciones de horneado de los granos de nueces se optimizaron en base a diferentes cultivares y métodos de horneado. Se determinó la influencia de las diferentes técnicas de horneado sobre las propiedades químicas de los aceites de nuez. Los resultados mostraron que el índice de acidez, el índice de peróxido y el período de inducción (PI) aumentaron significativamente en las muestras horneadas en comparación con las no horneadas. El mayor aumento en el PI fue de 6 a 17 h, lo que indica que el horneado puede mejorar la estabilidad oxidativa de los aceites de nuez y prolongar su vida útil. Varios componentes del aroma aumentaron después del horneado, sin embargo, entre las diferentes condiciones de horneado, se observó el aroma más fuerte en el aceite de nuez después del horneado durante 20 minutos con sacarosa $(107 \%)$ a $153{ }^{\circ} \mathrm{C}$. Sin embargo, el horneado tuvo poco efecto sobre la composición de ácidos grasos de las nueces.

PALABRAS CLAVE: Aceite de nuez; Calidad de aceites; Componentes aromáticos; Composición química; Técnica de horneado

Citation/Cómo citar este artículo: Niu BK, Olajide TM, Liu HA, Pasdar H, Weng XC. 2021. Effects of different baking techniques on the quality of walnut and its oil. Grasas Aceites 72 (2), e406. https://doi.org/10.3989/gya.1142192

Copyright: (C2021 CSIC. This is an open-access article distributed under the terms of the Creative Commons Attribution 4.0 International (CC BY 4.0) License. 


\section{INTRODUCTION}

Walnuts (Juglans regia L.) are mainly grown in East Asia, Southeastern Europe and North America, and are among the oldest tree nuts as well as the most economically important nut in the world (Gunn et al., 2010). There are approximately 20 species of Juglans regia L distributed throughout the world. China is the largest producer of walnuts in the world. In Yangbi, Yunnan Province, the authors saw a walnut tree dated over 1160 years old, which still bears fruit and is acclaimed to be the oldest walnut tree in China. Yangbi is also known as "the town of walnuts". Three main fatty acids in walnuts, oleic (18:1 $\omega-9)$, linoleic $(18: 2 \omega-6)$ and linolenic $(18: 3 \omega-3)$ acids account for about $90 \%$ of total walnut oil, and its ratio of $\omega-3$ to $\omega-6$ unsaturated fatty acids is more reasonable and can significantly lower blood lipids and prevent cardiovascular and cerebrovascular diseases (Abbey et al., 1994). Polyphenols, flavonoids and vitamin $\mathrm{E}$ in walnuts have good antioxidant and anti-aging effects (Zhao et al., 2014) which can protect functional fatty acids from autoxidation.

Baking is usually carried out to remove the pellicles of kernels, inactivate enzymes, destroy microorganisms and reduce water activity. Moreover, it can also be used to improve the color, crispy texture and flavor of products (BurdackFreitag and Schieberle, 2010). The thermal treatment applied during baking leads to physical changes such as dehydration (Amaral et al., 2006), color modifications (Alamprese et al., 2009), biochemical changes including lipid structure modification and improvement in alluring flavor formation through Maillard reaction (Martins et al., 2000). The Maillard reaction is a series of complex reactions between the carbonyl group of reducing sugars and amino groups of free amino acids, peptides and proteins (Hodge et al., 1953). So far, reaction models between free amino acids and carbonyl compounds have been studied extensively and suggested that different reaction mechanisms existed in regards to different reactants, e.g., free amino acids or peptides. Investigations using pure peptides in Maillard reaction models demonstrated that peptides could participate in the Maillard reaction through many pathways such as bond cleavage, cyclization, and glycation (Garbe et al., 2004).
Vaidya et al., (2013) showed that the baking of walnut kernels increased their oil's oxidative stability during storage in the dark. It has significant effects on the nutrients and quality of lipids in walnut oil. Ovenbaking is one of the best methods for processing walnuts because it preserves the quality of its lipids and some nutrients. Zhang et al., (2012) observed that increasing the temperature during the baking of walnuts from 60 to $90{ }^{\circ} \mathrm{C}$ in a gradient style, shortens drying time and improves oxidative stability compared to other baking condition and the products were of good quality. Santos et al., (2017) showed that all walnut flours contained about $42 \%$ protein and a significant amount of dietary fiber (17\%), and were not affected by the baking process. Ziaolhagh et al., (2017) optimized the temperature and time of the baking of walnut kernels used for producing walnut cream, as they aimed to extend the shelf-life of walnut cream by slowing its oxidation reactions and reducing oil separation. Finally, the temperature of $116^{\circ} \mathrm{C}$ for $12 \mathrm{~min}$ was chosen as the optimized baking conditions for producing walnut cream.

Herein, the baking technique was explored to optimize the parameters for the production of walnut oil with very desirable aroma, as studies in this research area are very limited.

\section{MATERIALS AND METHODS}

\subsection{Materials and chemicals}

Three walnut cultivars were donated by Yunnan Jiye Biological Co., Ltd. (Yunnan, China), and included "Yangbi walnut, Chuxiong walnut, (two districts in Yunnan)" and "Iron (i.e. very hard shell) walnut". The samples were stored at $4{ }^{\circ} \mathrm{C}$ before baking to maintain freshness.

All solvents used were of AR grade: Anhydrous ether, petroleum ether, ethanol (95\%), glacial acetic acid, chloroform, anhydrous methanol, potassium hydroxide, sodium hydroxide, anhydrous sodium carbonate, and potassium iodide were purchased from Sinopharm Chemical Reagent Co., Ltd. (Shanghai, China). Sodium thiosulfate, dichloromethane, n-hexane and sodium methanol were from Macklin (Shanghai, China).

\subsection{Baking procedure}

Three kinds of baking techniques were employed: baking without additives, baking with sucrose, and 
baking with sucrose and salt. Walnuts of all three categories were baked in a lab-scale electric oven with variability in temperature of $\pm 0.5^{\circ} \mathrm{C}$ (SM-522, Xinmai Machinery Co., Ltd., Jiangsu, China). First, the walnuts were manually cracked and shelled with a nutcracker to afford edible kernels before baking. Then the walnut kernels were rinsed with tap water for 1 minute, allowed to dry and $100 \pm 0.05 \mathrm{~g}$ were transferred into solutions of different concentrations of sucrose and/or salt for one hour. The walnut kernels were purposely soaked in these solutions in order to enhance their taste, flavor and appearance and also to study the effect of the additives on oxidative stability of the resulting walnut oil after baking. Nevertheless, soaking time should not be too long, otherwise walnut kernels may become soft, which would affect their taste. Next, the kernels were placed in the electric oven for baking at different times and temperatures, and turned over every 5 min. The baked walnut kernels were kept at room temperature to cool down.

\subsection{Optimization of baking parameters}

Baking without additives considered two factors: baking time and baking temperature. Walnut kernels were baked in the oven at seven levels of temperatures between 120 and $180^{\circ} \mathrm{C}$ at $10 \pm 0.5^{\circ} \mathrm{C}$ increments for 5-25 min. The baked walnut kernels were then cooled at room temperature for an hour prior to sensory evaluation.

Baking with sucrose considered three factors: baking time, baking temperature and the amounts of sucrose added. An orthogonal experiment with 3 factors and 3 levels was designed to optimize baking conditions (Table 2). For Yangbi and Chuxiong walnuts, nine baking experiments were carried out at baking time (Yangbi: 10, 15, and 20 min; Chuxiong: 15, 20 and $25 \mathrm{~min}$ ), baking temperature 140, 150, $160{ }^{\circ} \mathrm{C}$ and sucrose amount (sucrose: walnut weight) 90,100 and $110 \%$ based on the single-factor test. For Iron walnuts, however, baking time was 15,20 , and 25 min, baking temperature $150,160,170{ }^{\circ} \mathrm{C}$ and sucrose amount was same as Yangbi and Chuxiong walnuts (sucrose: walnut weight) $90,100,110 \%$. The average response value $\mathrm{K}\left(\mathrm{K}_{1 \mathrm{j}}, \mathrm{K}_{2 \mathrm{j}}, \mathrm{K}_{3 \mathrm{j}}\right)$ of the factors at each level was calculated separately, and the extreme analysis $R_{j}$ value of the effect of factor level on baking was also determined, indicating the order of influence i.e. the larger the $R_{j}$ value, the greater the influence of the factor on the sensory evaluation score (Zhao et al., 2014).

Baking with sucrose and salt involved four factors: baking time, baking temperature, the amounts of sucrose and salt added, and an orthogonal experiment with 4 factors and 3 levels was designed to optimize baking conditions (Table 3 ). Similar conditions and orthogonal analysis similar to the baking with sucrose experiment were carried out in this section including an additional factor, the salt amount (salt: walnut weight), at 10,15 , and $20 \%$ on the basis of singlefactor test for the three walnut types.

\subsection{Sensory evaluation}

The sensory evaluation of the baked walnut kernels was carried out an hour after baking. 15 trained sensory assessors from the Food Science Department of Shanghai University, Shanghai, China, were selected and trained as panelists according to the standardized procedure (ISO/DIS 13299). The scorecard was developed according to a 10-point category scale (extremely dislike $=0$; extremely like $=10$ ), and each assessor was asked to assess the walnut kernels for overall quality based on shape, color, odor, and flavor. Sensory assessors were also asked to comment on what they liked or disliked about the samples.

\subsection{Extraction of walnut oil}

The extraction of walnut oil was performed according to the Soxhlet extraction method. Baked walnut kernels were finely ground for 1 min into paste by a pulverizer (FW100 model, Tianjin, China) and Soxhlet-extracted with petroleum ether (P.E) for $6 \mathrm{~h}$. The temperature was controlled so that the extracting solution could reflux once every 6 to $8 \mathrm{~min}$. Then, the solvent was removed by using a vacuum rotary evaporator (RE-52AA, Shanghai Yuhua Instrument Equipment Co., Ltd. Shanghai, China). The extracted oil was kept in sealed glass bottles at $4{ }^{\circ} \mathrm{C}$ until analysis.

\subsection{Physicochemical properties of walnut oil}

Kernel yield was measured according to the Chinese National Standard for quality testing GB/T 5499-2008.

The protein content in walnuts was determined according to the Kjeldahl method. The walnut kernels were ground into powder and digested in a digestion 
apparatus. Protein content was determined using a SKD-2000 automatic Kjeldahl nitrogen analyzer (Shanghai Peiou Analytical Instrument Co., Ltd.).

Oxidative stability. The peroxide value (PV) was determined according to the Chinese National Standard method GB 5009.227-2016. PV is commonly used to determine oxidative rancidity in oils and fats. The Acid value (AV) is another useful oil quality parameter, which involves the quantification of the amount of free fatty acids (Olajide et al., 2018), and in this study was done based on the Chinese National Standard method, GB 5009.229-2016. The oxidative stability index (OSI), also known as induction period (IP), was evaluated by applying an accelerated automated test using the 743 Rancimat (Metrohm Co., Herisau, Switzerland) method according to a previous method with slight modifications (Olajide et al., 2020). Different extracted oil samples $(5 \pm 0.05 \mathrm{~g})$ were weighed into test tubes and connected to the Rancimat. Air at 20 $\mathrm{L} / \mathrm{h}$ flow rate was bubbled through the oil heated at $100 \pm 0.2^{\circ} \mathrm{C}$.

\subsection{Fatty acid composition}

The fatty acids methyl esters (FAMEs) of walnut oil were prepared according to the AOCS method Ce 1b-89 (AOCS, 1993).

All GC-MS analyses were performed on a Shimadzu GC2010A (Kyoto, Japan) gas chromatography instrument coupled with a GCMSQP2010 quadrupole mass spectrometer (Shimadzu). The gas chromatographic system was equipped with an HP-Innowax PEG capillary column, $30 \mathrm{~m}$ length and $0.25 \mathrm{~mm}$ i.d., and the chromatographic conditions were the same as Verardo et al., (2013).

Individual FAMEs were identified by comparison to the NIST98 (National Institute of Standards and Technology, Gaithersburg, MD, USA) mass spectral library as well as to the Wiley 6.0 (Wiley, New York, NY, USA) mass spectral library. A relative amount of each fatty acid methyl esters was expressed by using the peak area normalization method.

\subsection{Determination of volatile flavor components}

Simultaneous distillation-solvent extraction (SDE) was carried out in a micro-version apparatus. Dichloromethane was used as solvent. For each extraction, $10 \pm 0.05 \mathrm{~g}$ walnut oil and $250 \mathrm{ml}$ distilled water were added to a 500-ml flask, and 30 $\mathrm{ml}$ dichloromethane were added into another 50-ml flask. Steam distillation lasted two hours while the solvent extraction was continued for a further 15 min. The extract was placed in the refrigerator at $-18^{\circ} \mathrm{C}$ for $12 \mathrm{~h}$. Dry anhydrous sodium sulfate was used to dehydrate the extract, which was then finally concentrated to $2 \mathrm{ml}$ with a nitrogen purge. The concentrate was stored at $-4{ }^{\circ} \mathrm{C}$ for GC-MS analysis.

All SDE extracts were analyzed using a Shimadzu GC2010A (Kyoto, Japan) gas chromatography instrument coupled with a GCMS-QP2010 quadrupole mass spectrometer (Shimadzu). A 30 $\mathrm{m} \times 0.25 \mathrm{~mm}$ CP-Wax 52CB quartz capillary column with $0.25-\mu \mathrm{m}$ film thickness was used to resolve the volatiles. The method of GC-MS referred to the method of Wang et al., (2015).

The mass spectral identifications of the volatiles were carried out by comparison to the NIST98 (National Institute of Standards and Technology, Gaithersburg, MD, USA) mass spectral library as well as to the Wiley 6.0 (Wiley, New York, NY, USA) mass spectral library.

\subsection{Statistical analysis}

All assays were carried out in duplicate or triplicate and values are expressed as mean \pm standard deviation (SD). Data were analyzed by analysis of variance (ANOVA) and Duncan's multiple range test $(P<0.05)$ using SPSS software (PASW Statistics 18, SPSS Inc, Chicago, IL, USA) and MS Office Excel 2010 (Microsoft Co., Redmond, WA, USA).

\section{RESULTS AND DISCUSSION}

\subsection{Optimization of baking parameters}

\subsubsection{Baking without additives}

Table 1 shows the sensory evaluation scores of the threekinds of walnuts at different baking temperatures and time combinations. When the temperature was lower than $140{ }^{\circ} \mathrm{C}$, the aroma of baked walnuts became stronger and the score was higher with the extension of baking time because Maillard reaction increased. When baking temperature was higher than $150{ }^{\circ} \mathrm{C}$, and the baking time longer than 20 min, a burnt taste became prominent. For example, when baking was done at $180^{\circ} \mathrm{C}$ for $25 \mathrm{~min}$, a strong 
Effects of different baking techniques on the quality of walnut and its oil $\bullet$

TABLE 1. Sensory evaluation scores for the three kinds of walnuts baked at different time and temperature without additives.

\begin{tabular}{|c|c|c|c|c|c|c|c|c|}
\hline \multirow{2}{*}{ Cultivar } & \multirow{2}{*}{$\begin{array}{l}\text { Time } \\
\text { (min) }\end{array}$} & \multicolumn{7}{|c|}{ Temperature $\left({ }^{\circ} \mathrm{C}\right)$} \\
\hline & & 120 & 130 & 140 & 150 & 160 & 170 & 180 \\
\hline \multirow{5}{*}{ Yangbi walnut } & 5 & $3.0 \pm 0.1$ & $4.1 \pm 0.2$ & $5.2 \pm 0.4$ & $6.4 \pm 0.4$ & $6.0 \pm 0.3$ & $5.6 \pm 0.2$ & $5.3 \pm 0.2$ \\
\hline & 10 & $3.8 \pm 0.3$ & $5.0 \pm 0.4$ & $6.6 \pm 0.3$ & $7.0 \pm 0.1$ & $6.4 \pm 0.2$ & $5.5 \pm 0.2$ & $5.0 \pm 0.1$ \\
\hline & 15 & $4.1 \pm 0.4$ & $5.6 \pm 0.2$ & $6.4 \pm 0.2$ & $7.5 \pm 0.3$ & $5.8 \pm 0.4$ & $6.3 \pm 0.3$ & 0 \\
\hline & 20 & $5.3 \pm 0.2$ & $6.2 \pm 0.3$ & $5.1 \pm 0.3$ & 0 & 0 & 0 & 0 \\
\hline & 25 & $4.7 \pm 0.3$ & $4.9 \pm 0.2$ & $5.7 \pm 0.4$ & 0 & 0 & 0 & 0 \\
\hline \multirow{5}{*}{$\begin{array}{l}\text { Chuxiong } \\
\text { walnut }\end{array}$} & 5 & $2.3 \pm 0.2$ & $3.9 \pm 0.2$ & $5.4 \pm 0.4$ & $6.0 \pm 0.2$ & $6.4 \pm 0.1$ & $5.4 \pm 0.2$ & $4.9 \pm 0.2$ \\
\hline & 10 & $3.7 \pm 0.3$ & $5.3 \pm 0.3$ & $6.3 \pm 0.4$ & $6.7 \pm 0.3$ & $6.0 \pm 0.2$ & $5.1 \pm 0.1$ & $4.5 \pm 0.2$ \\
\hline & 15 & $4.5 \pm 0.1$ & $5.7 \pm 0.2$ & $6.7 \pm 0.1$ & $6.6 \pm 0.3$ & $5.5 \pm 0.4$ & $5.9 \pm 0.1$ & 0 \\
\hline & 20 & $4.8 \pm 0.3$ & $6.0 \pm 0.3$ & $7.3 \pm 0.3$ & 0 & 0 & 0 & 0 \\
\hline & 25 & $4.1 \pm 0.3$ & $4.2 \pm 0.4$ & $6.0 \pm 0.3$ & 0 & 0 & 0 & 0 \\
\hline \multirow{5}{*}{ Iron walnut } & 5 & $3.1 \pm 0.3$ & $4.2 \pm 0.2$ & $5.3 \pm 0.1$ & $6.3 \pm 0.1$ & $6.4 \pm 0.2$ & $5.4 \pm 0.3$ & $4.9 \pm 0.2$ \\
\hline & 10 & $3.8 \pm 0.2$ & $5.3 \pm 0.3$ & $6.4 \pm 0.2$ & $6.5 \pm 0.3$ & $6.8 \pm 0.2$ & $5.3 \pm 0.2$ & $4.7 \pm 0.3$ \\
\hline & 15 & $4.4 \pm 0.3$ & $5.7 \pm 0.2$ & $5.7 \pm 0.2$ & $6.8 \pm 0.2$ & $7.1 \pm 0.3$ & $5.9 \pm 0.2$ & $5.5 \pm 0.2$ \\
\hline & 20 & $4.7 \pm 0.4$ & $5.7 \pm 0.2$ & $6.2 \pm 0.3$ & $6.5 \pm 0.3$ & $6.5 \pm 0.4$ & 0 & 0 \\
\hline & 25 & $3.9 \pm 0.3$ & $4.2 \pm 0.1$ & $5.8 \pm 0.2$ & $5.9 \pm 0.1$ & 0 & 0 & 0 \\
\hline
\end{tabular}

Values are expressed as mean \pm standard deviation of duplicate determinations.

$n=15$ responses for sensory evaluation.

The scorecard was developed with a 10-point category scale (dislike $=0$; extremely like $=10)$.

unpleasant taste was produced, thereby zeroing the sensory evaluation score. Finally, according to the average highest score for the sensory evaluation, the best non-additive baking method for the three kinds of walnuts was obtained. The time and temperature of Yangbi walnuts baked without additives were 150 ${ }^{\circ} \mathrm{C}$, for $15 \mathrm{~min}$; Chuxiong walnuts baked without additives were $150^{\circ} \mathrm{C}$, for $20 \mathrm{~min}$; and Iron walnuts were $160{ }^{\circ} \mathrm{C}$, for $15 \mathrm{~min}$. As can be seen from the data, the baking of Iron walnuts required more time and a higher temperature because they were harder and so required a higher temperature to bake than the other two cultivars.

\subsubsection{Baking with sucrose}

The sucrose-added baking experiment was carried out under the same conditions as above. Firstly, a single-factor experiment design was carried out to determine the range of the amount of sucrose. The sucrose amounts tested (sucrose: walnut weight) were $70,80,90,100,110$ and $120 \%$. The results of subsequent sensory evaluation, show that the increase in sucrose amount corresponded to higher sensory scores for the three walnuts (Figure 1 ). When the sucrose amount exceeded $90 \%$, the sensory score did not change much. Therefore, 90 , 100 and $110 \%$ sucrose amounts were selected as the three levels for the orthogonal experiment. The $\mathrm{L}_{9}\left(3^{3}\right)$ orthogonal experiment was carried out after determining the range of sucrose amount.

Three factors and three levels of orthogonal experiments were carried out on three kinds of walnuts. The results are shown in Table 2. For the Yangbi walnut, the maximum sensory score was 8.1. However, the best score could not be selected based on the outcomes in Table 2 alone, so a further orthogonal analysis was done. Thus, the $\mathrm{K}$ and $\mathrm{R}$ values were calculated and listed in Table 2 . As seen, the influence to the sensory score was in the order: 
A (time) $>\mathrm{B}$ (temperature) $>\mathrm{C}$ (sucrose amount) according to the $\mathrm{R}$ values. The baking time was found to be the most important determinant factor for the sensory evaluation score. In other words, the maximum sensory score for the baking technique with sucrose was obtained when temperature, time and sucrose amount added to Yangbi walnut were $150{ }^{\circ} \mathrm{C}, 15 \mathrm{~min}$ and $110 \%$, respectively. Using the same analysis method, the optimal baking conditions for Chuxiong walnuts and Iron walnuts were as follows: the baking temperature, baking time and sucrose amount added for Chuxiong walnuts were $150{ }^{\circ} \mathrm{C}, 20 \mathrm{~min}$ and $110 \%$, and $160{ }^{\circ} \mathrm{C}, 25 \mathrm{~min}$ and $100 \%$, respectively for Iron walnuts.

\subsubsection{Baking with sucrose and salt}

Similar optimal baking conditions to baking with sucrose were employed here. Firstly, a single factor experiment of salt addition was carried out to determine the range of salt amount, 5, 10, 15, 20 , and $25 \%$ of salt amounts (salt: walnut weight) were selected. After the baking test, the walnuts were subjected to sensory evaluation. The results are shown in Figure 2, and from there it can be seen that the sensory score showed a positive correlation trend within $5 \% \sim 15 \%$ of the salt amount. When

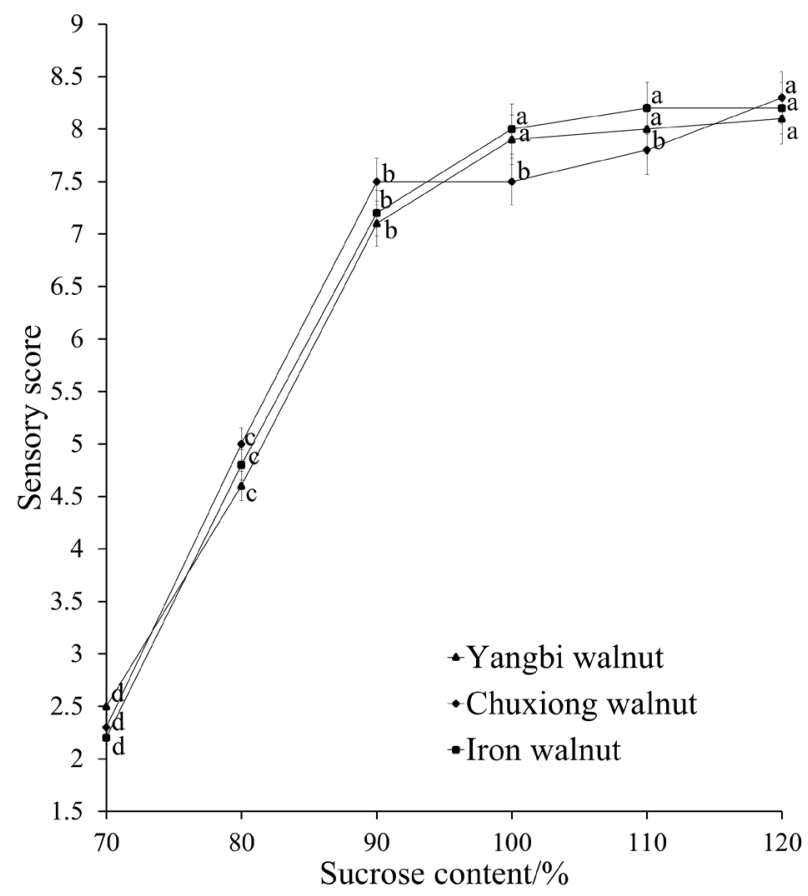

FIGURE 1. Single-factor experiments on different amounts of sucrose added during walnut baking. Each value is expressed as Mean \pm $\mathrm{SD}(\mathrm{n}=3)$. Different letters are significantly different at $\mathrm{P}<0.05$ according to Duncan's test.

the salt amount was higher than $15 \%$, the sensory evaluation score began to decrease slightly. Therefore, 10, 15 and $20 \%$ salt amounts were

TABLE 2. Orthogonal experiment design and analysis for baking with sucrose.

\begin{tabular}{|c|c|c|c|c|c|c|c|c|c|}
\hline \multirow[b]{2}{*}{ Cultivar } & \multirow[b]{2}{*}{ Level } & \multicolumn{3}{|c|}{ Orthogonal test factors } & \multirow[b]{2}{*}{ Code } & \multicolumn{4}{|c|}{ Analysis } \\
\hline & & $\begin{array}{c}\mathrm{A} \\
\text { (time/ } \\
\text { min) }\end{array}$ & $\begin{array}{c}\mathrm{B} \\
\left(\text { temperature } /{ }^{\circ} \mathrm{C} \text { ) }\right.\end{array}$ & $\begin{array}{c}\mathrm{C} \\
\text { (sucrose } \\
\text { amount } / \% \text { ) }\end{array}$ & & $\begin{array}{c}\mathrm{A} \\
(\mathrm{min})\end{array}$ & $\begin{array}{c}\mathrm{B} \\
\left({ }^{\circ} \mathrm{C}\right)\end{array}$ & $\begin{array}{c}\mathrm{C} \\
(\%)\end{array}$ & $\begin{array}{c}\text { Sensory } \\
\text { evaluation }\end{array}$ \\
\hline \multirow{13}{*}{$\begin{array}{l}\text { Yangbi } \\
\text { walnut }\end{array}$} & 1 & 10 & 140 & 90 & 1 & 1 & 1 & 1 & $5.6 \pm 0.3^{\mathrm{c}}$ \\
\hline & 2 & 15 & 150 & 100 & 2 & 1 & 2 & 2 & $7.2 \pm 0.3^{b}$ \\
\hline & 3 & 20 & 160 & 110 & 3 & 1 & 3 & 3 & $7 \pm 0.1^{\mathrm{b}}$ \\
\hline & & & & & 4 & 2 & 1 & 2 & $8.1 \pm 0.3^{\mathrm{a}}$ \\
\hline & & & & & 5 & 2 & 2 & 3 & $7.8 \pm 0.2^{\mathrm{a}}$ \\
\hline & & & & & 6 & 2 & 3 & 1 & $6.7 \pm 0.2^{\mathrm{b}}$ \\
\hline & & & & & 7 & 3 & 1 & 3 & $7.1 \pm 0.3^{b}$ \\
\hline & & & & & 8 & 3 & 2 & 1 & $7 \pm 0.4^{b}$ \\
\hline & & & & & 9 & 3 & 3 & 2 & $4.4 \pm 0.4^{\mathrm{d}}$ \\
\hline & & & & & $\mathrm{K}_{1 \mathrm{j}}$ & 6.6 & 6.9 & 6.4 & \\
\hline & & & & & $\mathrm{K}_{2 \mathrm{j}}$ & 7.5 & 7.3 & 6.6 & \\
\hline & & & & & $\mathrm{K}_{3 \mathrm{j}}$ & 6.2 & 6.0 & 7.3 & \\
\hline & & & & & $\mathrm{R}_{\mathrm{j}}$ & 1.4 & 1.3 & 0.8 & \\
\hline
\end{tabular}


Effects of different baking techniques on the quality of walnut and its oil $\bullet$

\begin{tabular}{|c|c|c|c|c|c|c|c|c|c|}
\hline \multirow[b]{2}{*}{ Cultivar } & \multirow[b]{2}{*}{ Level } & \multicolumn{3}{|c|}{ Orthogonal test factors } & \multirow[b]{2}{*}{ Code } & \multicolumn{4}{|c|}{ Analysis } \\
\hline & & $\begin{array}{c}\mathrm{A} \\
\text { (time/ } \\
\text { min) } \\
\end{array}$ & $\begin{array}{c}\mathrm{B} \\
\text { (temperature } /{ }^{\circ} \mathrm{C} \text { ) }\end{array}$ & $\begin{array}{c}\mathrm{C} \\
\text { (sucrose } \\
\text { amount } / \% \text { ) } \\
\end{array}$ & & $\begin{array}{c}\text { A } \\
(\mathrm{min})\end{array}$ & $\begin{array}{c}\mathrm{B} \\
\left({ }^{\circ} \mathrm{C}\right)\end{array}$ & $\begin{array}{c}C \\
(\%)\end{array}$ & $\begin{array}{c}\text { Sensory } \\
\text { evaluation }\end{array}$ \\
\hline \multirow{13}{*}{$\begin{array}{l}\text { Chu- } \\
\text { xiong } \\
\text { walnut }\end{array}$} & 1 & 15 & 140 & 90 & 1 & 1 & 1 & 1 & $6.2 \pm 0.2^{\mathrm{f}}$ \\
\hline & 2 & 20 & 150 & 100 & 2 & 1 & 2 & 2 & $7.8 \pm 0.2^{\mathrm{b}}$ \\
\hline & 3 & 25 & 160 & 110 & 3 & 1 & 3 & 3 & $7.3 \pm 0.3^{\mathrm{cd}}$ \\
\hline & & & & & 4 & 2 & 1 & 2 & $7.9 \pm 0.2^{b}$ \\
\hline & & & & & 5 & 2 & 2 & 3 & $8.5 \pm 0.3^{\mathrm{a}}$ \\
\hline & & & & & 6 & 2 & 3 & 1 & $6.9 \pm 0.1^{\mathrm{de}}$ \\
\hline & & & & & 7 & 3 & 1 & 3 & $6.8 \pm 0.2^{\mathrm{e}}$ \\
\hline & & & & & 8 & 3 & 2 & 1 & $7.6 \pm 0.3^{\mathrm{bc}}$ \\
\hline & & & & & 9 & 3 & 3 & 2 & $4.7 \pm 0.2^{\mathrm{g}}$ \\
\hline & & & & & $\mathrm{K}_{1 \mathrm{j}}$ & 7.1 & 7.0 & 6.9 & \\
\hline & & & & & $\mathrm{K}_{2 \mathrm{j}}$ & 7.8 & 8.0 & 6.8 & \\
\hline & & & & & $\mathrm{K}_{3 \mathrm{j}}$ & 6.4 & 6.3 & 7.5 & \\
\hline & & & & & $R_{j}$ & 1.4 & 1.7 & 0.7 & \\
\hline \multirow{13}{*}{$\begin{array}{l}\text { Iron } \\
\text { walnut }\end{array}$} & 1 & 15 & 150 & 90 & 1 & 1 & 1 & 1 & $6.2 \pm 0.2^{\mathrm{e}}$ \\
\hline & 2 & 20 & 160 & 100 & 2 & 1 & 2 & 2 & $7.9 \pm 0.2^{b}$ \\
\hline & 3 & 25 & 170 & 110 & 3 & 1 & 3 & 3 & $4.7 \pm 0.3^{\mathrm{f}}$ \\
\hline & & & & & 4 & 2 & 1 & 2 & $6.9 \pm 0.3^{\mathrm{d}}$ \\
\hline & & & & & 5 & 2 & 2 & 3 & $6.8 \pm 0.2^{\mathrm{d}}$ \\
\hline & & & & & 6 & 2 & 3 & 1 & $7.6 \pm 0.1^{\mathrm{bc}}$ \\
\hline & & & & & 7 & 3 & 1 & 3 & $8.5 \pm 0.3^{\mathrm{a}}$ \\
\hline & & & & & 8 & 3 & 2 & 1 & $7.9 \pm 0.2^{b}$ \\
\hline & & & & & 9 & 3 & 3 & 2 & $7.3 \pm 0.3^{\mathrm{c}}$ \\
\hline & & & & & $\mathrm{K}_{1 \mathrm{j}}$ & 6.3 & 7.2 & 7.2 & \\
\hline & & & & & $\mathrm{K}_{2 \mathrm{j}}$ & 7.1 & 7.5 & 7.4 & \\
\hline & & & & & $\mathrm{K}_{3 \mathrm{j}}$ & 7.9 & 6.5 & 6.7 & \\
\hline & & & & & $R_{j}$ & 1.6 & 1.0 & 0.7 & \\
\hline
\end{tabular}

Values are expressed as mean \pm standard deviation of triplicate determinations.

Means in the same row with different letters are significantly different $(P<0.05)$ according to Duncan's multiple range test.

$n=15$ responses for sensory evaluation.

The scorecard was developed with 10 -point category scale $($ dislike $=0$; extremely like $=10)$

$\mathrm{K}_{1 \mathrm{j}}, \mathrm{K}_{2 \mathrm{j}}$, and $\mathrm{K}_{3 \mathrm{j}}$ are the average values of sensory scores corresponding to the factors in different levels.

$\mathrm{R}_{\mathrm{j}}$ refers to the result of extreme analysis.

selected as the three levels for the orthogonal experiment. The $\mathrm{L}_{9}\left(3^{4}\right)$ orthogonal experiment was carried out after determining the range of salt addition.
Table 3 shows that the time, temperature, amounts of sucrose and salt added had the same effect on the baking of the three walnuts types: $\mathrm{D}$ (salt amount) $>\mathrm{A}$ (time) $>\mathrm{B}$ (temperature) $>\mathrm{C}$ (sucrose amount). 
$8 \cdot$ B.K. Niu, T.M. Olajide, H.A. Liu, H. Pasdar and X.C. Weng

TABLE 3. Orthogonal experiment design and analysis for baking with sucrose and salt.

\begin{tabular}{|c|c|c|c|c|c|c|c|c|c|c|c|}
\hline \multirow[b]{2}{*}{ Cultivar } & \multirow[b]{2}{*}{ Level } & \multicolumn{4}{|c|}{ Orthogonal test factors } & \multirow[b]{2}{*}{ Code } & \multicolumn{5}{|c|}{ Analysis } \\
\hline & & $\begin{array}{c}\mathrm{A} \\
\text { (time/ } \\
\text { min) }\end{array}$ & $\begin{array}{c}\mathrm{B} \\
\text { (temperatu- } \\
\text { re } /{ }^{\circ} \mathrm{C} \text { ) }\end{array}$ & $\begin{array}{c}\mathrm{C} \\
\text { (sucrose } \\
\text { amount } / \% \text { ) }\end{array}$ & $\begin{array}{c}\mathrm{D} \\
\text { (salt } \\
\text { amount/\%) }\end{array}$ & & $\underset{(\min )}{\mathbf{A}}$ & $\begin{array}{c}\text { B } \\
\left({ }^{\circ} \mathrm{C}\right)\end{array}$ & $\begin{array}{c}\mathrm{C} \\
(\%)\end{array}$ & $\begin{array}{c}\text { D } \\
(\%)\end{array}$ & $\begin{array}{c}\text { Sensory } \\
\text { evaluation }\end{array}$ \\
\hline \multirow{13}{*}{$\begin{array}{l}\text { Yangbi } \\
\text { walnut }\end{array}$} & 1 & 10 & 140 & 90 & 10 & 1 & 1 & 1 & 1 & 1 & $6.2 \pm 0.2^{\mathrm{e}}$ \\
\hline & 2 & 15 & 150 & 100 & 15 & 2 & 1 & 2 & 2 & 2 & $7.8 \pm 0.1^{\mathrm{b}}$ \\
\hline & 3 & 20 & 160 & 110 & 20 & 3 & 1 & 3 & 3 & 3 & $7.3 \pm 0.3^{\text {cd }}$ \\
\hline & & & & & & 4 & 2 & 1 & 2 & 3 & $8.6 \pm 0.4^{\mathrm{a}}$ \\
\hline & & & & & & 5 & 2 & 2 & 3 & 1 & $6.9 \pm 0.2^{\mathrm{d}}$ \\
\hline & & & & & & 6 & 2 & 3 & 1 & 2 & $7.2 \pm 0.2^{\mathrm{d}}$ \\
\hline & & & & & & 7 & 3 & 1 & 3 & 2 & $7.6 \pm 0.2^{\mathrm{bc}}$ \\
\hline & & & & & & 8 & 3 & 2 & 1 & 3 & $5.9 \pm 0.2^{\mathrm{e}}$ \\
\hline & & & & & & 9 & 3 & 3 & 2 & 1 & $4.7 \pm 0.2^{\mathrm{f}}$ \\
\hline & & & & & & $\mathrm{K}_{\mathrm{lj}}$ & 7.1 & 7.5 & 6.4 & 5.9 & \\
\hline & & & & & & $\mathrm{K}_{2 \mathrm{j}}$ & 7.6 & 6.9 & 7.0 & 7.5 & \\
\hline & & & & & & $\mathrm{K}_{3 \mathrm{j}}$ & 6.1 & 6.4 & 7.3 & 7.3 & \\
\hline & & & & & & $\mathrm{R}_{\mathrm{j}}$ & 1.5 & 1.1 & 0.8 & 1.6 & \\
\hline \multirow{13}{*}{$\begin{array}{l}\text { Chuxiong } \\
\text { walnut }\end{array}$} & 1 & 15 & 140 & 90 & 10 & 1 & 1 & 1 & 1 & 1 & $5.9 \pm 0.1^{\mathrm{e}}$ \\
\hline & 2 & 20 & 150 & 100 & 15 & 2 & 1 & 2 & 2 & 2 & $6.8 \pm 0.3^{\mathrm{d}}$ \\
\hline & 3 & 25 & 160 & 110 & 20 & 3 & 1 & 3 & 3 & 3 & $7.1 \pm 0.4^{\mathrm{d}}$ \\
\hline & & & & & & 4 & 2 & 1 & 2 & 3 & $8.5 \pm 0.2^{\mathrm{a}}$ \\
\hline & & & & & & 5 & 2 & 2 & 3 & 1 & $6.2 \pm 0.1^{\mathrm{e}}$ \\
\hline & & & & & & 6 & 2 & 3 & 1 & 2 & $7.9 \pm 0.2^{b}$ \\
\hline & & & & & & 7 & 3 & 1 & 3 & 2 & $7.5 \pm 0.2^{\mathrm{c}}$ \\
\hline & & & & & & 8 & 3 & 2 & 1 & 3 & $5.2 \pm 0.1^{\mathrm{f}}$ \\
\hline & & & & & & 9 & 3 & 3 & 2 & 1 & $6.1 \pm 0.2^{\mathrm{e}}$ \\
\hline & & & & & & $\mathrm{K}_{1 \mathrm{j}}$ & 6.6 & 7.3 & 6.3 & 6.1 & \\
\hline & & & & & & $\mathrm{K}_{2 \mathrm{j}}$ & 7.5 & 6.1 & 7.1 & 7.4 & \\
\hline & & & & & & $\mathrm{K}_{3 \mathrm{j}}$ & 6.3 & 7.0 & 6.9 & 6.9 & \\
\hline & & & & & & $\mathrm{R}_{\mathrm{j}}$ & 1.3 & 1.2 & 0.8 & 1.3 & \\
\hline \multirow{13}{*}{ Iron walnut } & 1 & 20 & 150 & 90 & 10 & 1 & 1 & 1 & 1 & 1 & $5.5 \pm 0.3^{\mathrm{e}}$ \\
\hline & 2 & 25 & 160 & 100 & 15 & 2 & 1 & 2 & 2 & 2 & $8.6 \pm 0.3^{\mathrm{a}}$ \\
\hline & 3 & 30 & 170 & 110 & 20 & 3 & 1 & 3 & 3 & 3 & $6.1 \pm 0.2^{\mathrm{d}}$ \\
\hline & & & & & & 4 & 2 & 1 & 2 & 3 & $5.4 \pm 0.4^{\mathrm{e}}$ \\
\hline & & & & & & 5 & 2 & 2 & 3 & 1 & $7.8 \pm 0.3^{b}$ \\
\hline & & & & & & 6 & 2 & 3 & 1 & 2 & $8.5 \pm 0.3^{\mathrm{a}}$ \\
\hline & & & & & & 7 & 3 & 1 & 3 & 2 & $7.2 \pm 0.1^{\mathrm{c}}$ \\
\hline & & & & & & 8 & 3 & 2 & 1 & 3 & $4.8 \pm 0.3^{\mathrm{f}}$ \\
\hline & & & & & & 9 & 3 & 3 & 2 & 1 & $5.0 \pm 0.3^{\text {ef }}$ \\
\hline & & & & & & $\mathrm{K}_{1 \mathrm{j}}$ & 6.7 & 6.0 & 6.3 & 6.1 & \\
\hline & & & & & & $\mathrm{K}_{2 \mathrm{j}}$ & 7.2 & 7.1 & 6.3 & 8.1 & \\
\hline & & & & & & $\mathrm{K}_{3 \mathrm{j}}$ & 5.7 & 6.5 & 7.0 & 5.4 & \\
\hline & & & & & & $\mathrm{R}_{\mathrm{i}}$ & 1.6 & 1.0 & 0.8 & 2.7 & \\
\hline
\end{tabular}

Values are means \pm standard deviations of triplicate determinations.

Means in the same row with different letters are significantly different $(P<0.05)$ according to Duncan's multiple range test. $n=15$ responses for sensory evaluation.

The scorecard was developed with a 10-point category scale (disliked $=0$; extremely liked $=10$ )

$\mathrm{K}_{1 \mathrm{j}}, \mathrm{K}_{2 \mathrm{j}}$, and $\mathrm{K}_{3 \mathrm{j}}$ are the average values of sensory scores corresponding to the factors in different levels.

$\mathrm{R}_{\mathrm{j}}$ refers to the result of extreme analysis. 
Nevertheless, the effect of salt addition on the sensory score of baked walnuts was most significant, i.e., a very high salt amount caused an obvious salty taste in the walnuts. Although the amounts of sucrose added had the smallest effect on baking, there is no denying its influence on the taste of the baked walnuts. It can be concluded that the optimum baking conditions of the three walnut types with sucrose and salt were as follows: the baking temperature of the Yangbi walnut was $150{ }^{\circ} \mathrm{C}$, baking time $15 \mathrm{~min}$, sucrose amount $110 \%$ and the salt amount $15 \%$; Chuxiong walnut is $150{ }^{\circ} \mathrm{C}$, baking time $20 \mathrm{~min}$, sucrose amount $110 \%$ and salt amount $15 \%$; Iron walnut was $160^{\circ} \mathrm{C}$, baking time $25 \mathrm{~min}$, sucrose amount $100 \%$ and the salt amount $15 \%$.

\subsection{Physicochemical properties}

Firstly, the physical characteristics of the three walnuts were compared based on their kernel productivity, fat content and protein content. The calculated data showed that the difference between the kernel yields of Yangbi and Chuxiong walnuts was not significant, 54.6 and $52.1 \%$, respectively. However, the kernel productivity of Iron walnuts was significantly lower than that of Yangbi and Chuxiong, at only $30.4 \%$. Their oil contents were slightly similar: the Chuxiong walnut kernel was $64.7 \%$, which was higher than those of the other two walnuts; Iron walnut was $60.7 \%$, and that of the Yangbi was $62.2 \%$. According to Hao et al., (2002), the oil content of walnut kernels should be in the range $63-69 \%$, and the protein content from 16 to $23 \%$. Contrary to the oil content, the protein content of Iron walnut kernels was the highest among the three walnut kernels, which was $14.9 \%$. The protein content of Chuxiong walnut kernels was slightly lower than that of Yangbi, at $11.0 \%$ and $13.4 \%$, respectively. The content of protein of the walnut kernels studied herein was lower than those grown in the USA, at $17.6 \%$, as reported by Sze-Tao et al., (2000) The variations in kernel productivity, oil and protein contents may be related to the different regions in which walnut trees were planted (Mao et al., 2014).

Oxidative stability. Walnut oil was extracted from walnuts processed according to different baking methods. The acid value (AV) and peroxide value (PV) of walnut oil were then evaluated

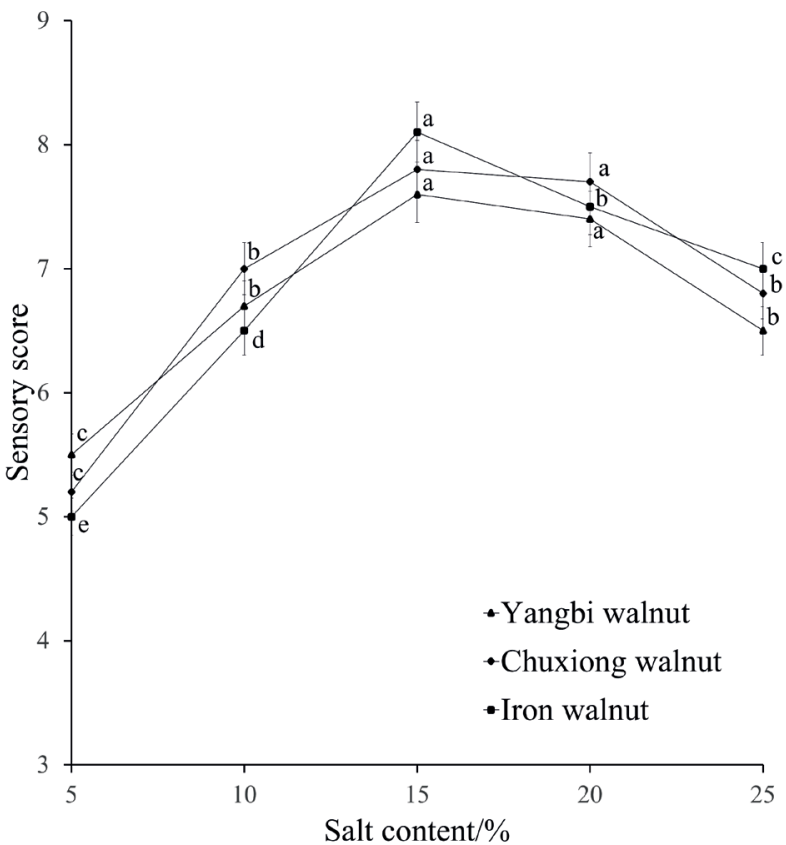

FIGURE 2. Single-factor experiments on different amounts of salt added during walnut baking. Each value is expressed as Mean \pm $\mathrm{SD}(\mathrm{n}=3)$. Different letters are significantly different at $\mathrm{P}<0.05$ according to Duncan's test.

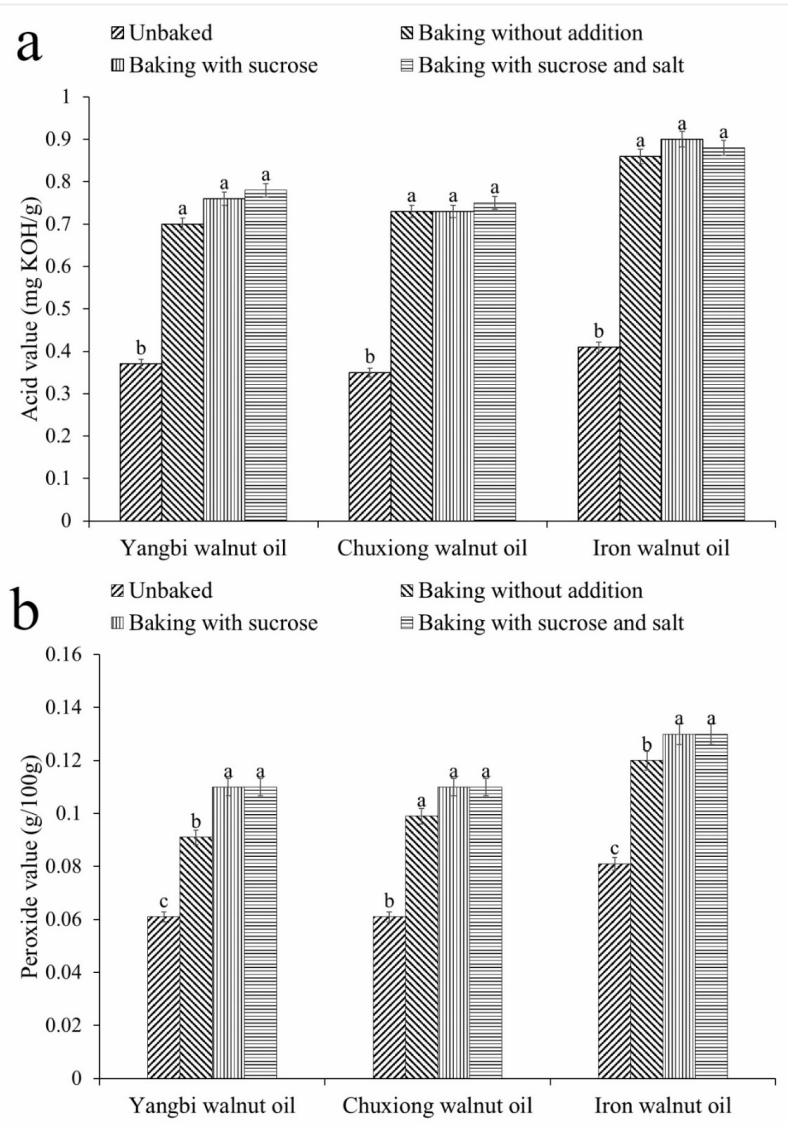

FIGURE 3. Effects of different baking techniques on the AV (a) and PV (b) of walnut oil. Each value is expressed as Mean $\pm \mathrm{SD}(\mathrm{n}=3)$. Different letters are significantly different at $\mathrm{P}<0.05$ according to Duncan's test. 
and compared. Under the action of lipase, some triglyceride molecules are hydrolyzed to release free fatty acids, which can influence the stability of oil (Fu et al., 2016). The AV can be used to express the degree of oil hydrolytic rancidity (Wang et al., 2015). The change in AV is shown in Figure 3(a). The AV of the three walnut oils were low prior to baking, but afterwards, the values increased significantly, and the three different baking processes had little to no positive effect on the AV of the walnut oils. It can be concluded that baking was the main influential factor in the change in AV, and the effect of adding sucrose or salt on the AV of walnut oil was small. This result is in agreement with the report of Vaidya et al., (2013). Branch et al., (1987) reported that the AV of oils extracted from baked peanuts were higher than those of unbaked peanuts.

The changes in PV in walnut oil is shown in Figure 3(b). Similar to the changes in AV, the PV of oils from the three walnut types were also greatly affected by baking. It significantly increased the PV of the walnut oils, especially those obtained by added sucrose, and sucrose and salt, which were slightly higher than without additives. Therefore, as with $\mathrm{AV}$, the main influential factor of the PV change in walnut oil was also baking, and the effect of adding sucrose or salt on the PV of walnut oil was small. This result is in agreement with the report of Vaidya et al., (2013) who showed that the PV of baked walnut oil was significantly higher; however, the rate of increase in baked walnut oil was lower than that of the unbaked one during storage.

The oxidative stability indexes of the different walnut oils processed with different techniques were measured by the Rancimat test and expressed as induction period (IP) in Figure 4. It is obvious that the change in IPs of Yangbi and Chuxiong walnut oils was similar, at 6 and $7 \mathrm{~h}$ when unbaked to 9 and $10 \mathrm{~h}$ after baking, respectively. The IP of Iron walnuts was significantly prolonged from 6 to $14 \mathrm{~h}$ after baking, which means that its oil oxidative stability greatly improved. In addition, some Maillard reaction products produced after baking, such as 4-hydroxy-2,5-dimethylfuran3-one and 2,3-dihydro-3,5-dihydroxy-6-methyl4-pyranone, have antioxidant properties and can effectively improve the oxidative stability of walnut oil. As shown in Figure 4 their antioxidant

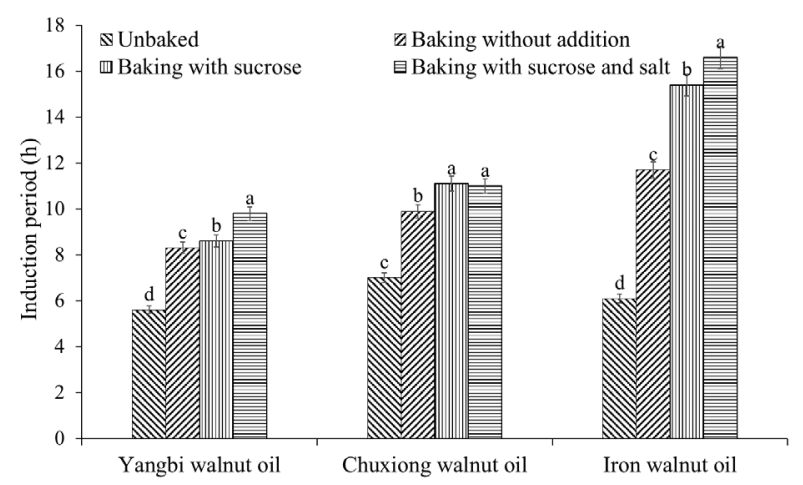

FIGURE 4. IPs of walnut oils extracted by different baking techniques. Each value is expressed as Mean $\pm \mathrm{SD}(\mathrm{n}=3)$. Different letters are significantly different at $\mathrm{P}<0.05$ according to Duncan's test.

capacities are similar to that of ascorbic acid (Aoyama et al., 1982). Their relative content was higher when baking was done with added substances than without, but the stability indexes obtained by baking with sucrose and sucrose with salt were stronger.

Therefore, it can be concluded that the three baking techniques can decrease the oxidative degradation of walnut oils and prolong their shelflife. This result is in agreement with the report of Vaidya et al., (2013) who showed that the baking of walnut kernels can be considered as an appropriate method for extending the oxidative stability of oil during storage.

\subsection{Fatty acid composition}

Both unbaked and baked walnut oils contained linoleic (57.43 and $58.4 \%$, respectively) in the highest proportion, followed by oleic (27.1 and $25.6 \%$, respectively), and linolenic acids (7.4 and $7.2 \%$, respectively), the total contents in palmitic and stearic acids was $<7 \%$ in both oils. The amount of linoleic acid contained in the walnut oil from the cultivar grown in China was basically the same as those reported for walnuts cultivated in Portugal (57.5-62.5\%), New Zealand (57.0$62.5 \%$ ), and Serbia (57.2-65.1\%) (Amaral et al., 2006). From the data we can draw the conclusion that there was no significant difference in the fatty acid composition between unbaked and baked walnut oils. Other studies also indicated that baking did not have an effect on the fatty acid composition of rice germ, safflower, or canola oils (Rabrenovic et al., 2011). 


\subsection{Volatile flavor components}

Table 4 shows some aroma components as identified by the GC-MS analysis of walnut oil obtained with different baking techniques. The relative content of each aroma component was calculated by normalizing the peak area of the gas chromatograph. The relative content in alcohol in the unbaked walnut oil was the highest, higher than that in the baked ones, and the content in 1-penten-3-alcohol was the highest. After baking, the ketones, acids and aldehydes in the walnut oil increased the most, while the alcohols decreased the most. The main aroma components in baked walnut oil were Maillard reaction products. The pyrazine compounds contained in baked walnut oil are the key aroma components of the baking aroma produced. Furthermore, the alcohols, hydrocarbons and other substances in the oil from baked walnuts without additives were more abundant than those in the oil from baked walnuts with sucrose, while the ketones, esters and aldehydes in the oil from baked walnuts

TABLE 4. Aroma components of walnut oil obtained by different baking techniques.

\begin{tabular}{|c|c|c|c|c|c|c|}
\hline \multirow{2}{*}{ Compound } & \multirow{2}{*}{$\begin{array}{c}\text { Molecular } \\
\text { formula }\end{array}$} & \multirow{2}{*}{$\begin{array}{c}\text { Molecular } \\
\text { weight }\end{array}$} & \multicolumn{3}{|c|}{ Relative content $/ \%$} & \multirow{2}{*}{$\begin{array}{c}\text { Aroma } \\
\text { descriptions }\end{array}$} \\
\hline & & & Sample 1 & Sample 2 & Sample 3 & \\
\hline Cyclobutanol & $\mathrm{C}_{4} \mathrm{H}_{8} \mathrm{O}$ & 72 & $5.4 \pm 0.1$ & - & - & \\
\hline 2-Methyl butyraldehyde & $\mathrm{C}_{5} \mathrm{H}_{10} \mathrm{O}$ & 86 & - & $0.9 \pm 0.1$ & $3.6 \pm 0.3$ & $\begin{array}{c}\text { Caramel, } \\
\text { nutty }\end{array}$ \\
\hline gamma-Butyrolactone & $\mathrm{C}_{4} \mathrm{H}_{6} \mathrm{O}_{2}$ & 86 & - & $1.8 \pm 0.2$ & $2.4 \pm 0.1$ & \\
\hline 1-Penten-3-ol & $\mathrm{C}_{5} \mathrm{H}_{10} \mathrm{O}$ & 86 & $42.7 \pm 0.6$ & $13.3 \pm 0.3$ & - & $\begin{array}{l}\text { Almond, } \\
\text { chocolaty }\end{array}$ \\
\hline 2-Methyl pyrazine & $\mathrm{C}_{5} \mathrm{H}_{6} \mathrm{~N}_{2}$ & 94 & - & $0.5 \pm 0.1$ & $0.4 \pm 0.1$ & $\begin{array}{c}\text { Rich baked } \\
\text { nuts }\end{array}$ \\
\hline Hexanal & $\mathrm{C}_{6} \mathrm{H}_{12} \mathrm{O}$ & 100 & $1.6 \pm 0.2^{\mathrm{c}}$ & $3.8 \pm 0.3^{\mathrm{b}}$ & $5.2 \pm 0.3^{\mathrm{a}}$ & Fat, nutty \\
\hline 2-Furaldehyde & $\mathrm{C}_{4} \mathrm{H}_{3} \mathrm{OCHO}$ & 96 & - & $1.5 \pm 0.1$ & $8.3 \pm 0.4$ & $\begin{array}{c}\text { Caramel, } \\
\text { baked food }\end{array}$ \\
\hline Cyclohexanone & $\mathrm{C}_{6} \mathrm{H}_{10} \mathrm{O}$ & 98 & $0.8 \pm 0.2^{\mathrm{c}}$ & $2.2 \pm 0.3^{\mathrm{b}}$ & $3.1 \pm 0.2^{\mathrm{a}}$ & \\
\hline 2,3-Pentanedione & $\mathrm{C}_{5} \mathrm{H}_{8} \mathrm{O}_{2}$ & 100 & - & $1.3 \pm 0.3$ & $0.8 \pm 0.1$ & $\begin{array}{c}\text { Cheese, grea- } \\
\text { se aroma }\end{array}$ \\
\hline 2,3-Dimethyl pyrazine & $\mathrm{C}_{6} \mathrm{H}_{8} \mathrm{~N}_{2}$ & 108 & $0.3 \pm 0.1^{\mathrm{b}}$ & $3.9 \pm 0.4^{\mathrm{a}}$ & $3.7 \pm 0.2^{\mathrm{a}}$ & $\begin{array}{c}\text { Nutty, baked, } \\
\text { chocolate }\end{array}$ \\
\hline 2,5-Dimethyl pyrazine & $\mathrm{C}_{6} \mathrm{H}_{8} \mathrm{~N}_{2}$ & 108 & - & $3.2 \pm 0.1$ & $2.1 \pm 0.3$ & Potato flavor \\
\hline Benzaldehyde & $\mathrm{C}_{7} \mathrm{H}_{6} \mathrm{O}$ & 106 & - & $0.8 \pm 0.1$ & $1.3 \pm 0.2$ & Nutty, fruity \\
\hline 2,4-Heptadienal & $\mathrm{C}_{7} \mathrm{H}_{10} \mathrm{O}$ & 110 & $2.9 \pm 0.3$ & - & - & $\begin{array}{c}\text { Fatty, nutty } \\
\text { aroma }\end{array}$ \\
\hline n-Hexanoic acid & $\mathrm{C}_{6} \mathrm{H}_{12} \mathrm{O}_{2}$ & 116 & $10.6 \pm 0.3^{\mathrm{c}}$ & $17.2 \pm 0.6^{\mathrm{a}}$ & $16.1 \pm 0.4^{\mathrm{b}}$ & \\
\hline 2-Ethyl-6-methyl pyrazine & $\mathrm{C}_{7} \mathrm{H}_{10} \mathrm{~N}_{2}$ & 122 & - & $2.1 \pm 0.4$ & $2.7 \pm 0.6$ & $\begin{array}{c}\text { Nuts, baking, } \\
\text { and sweet } \\
\text { aroma }\end{array}$ \\
\hline 5-Hydroxymethylfurfural & $\mathrm{C}_{6} \mathrm{H}_{6} \mathrm{O}_{3}$ & 126 & $12.5 \pm 0.8^{\mathrm{c}}$ & $26.3 \pm 0.6^{\mathrm{a}}$ & $21.1 \pm 0.5^{b}$ & \\
\hline 4-Hydroxy-2,5-dimethyl furan-3-one & $\mathrm{C}_{6} \mathrm{H}_{8} \mathrm{O}_{3}$ & 128 & $0.6 \pm 0.1^{\mathrm{c}}$ & $3.2 \pm 0.1^{\mathrm{b}}$ & $5.4 \pm 0.1^{\mathrm{a}}$ & \\
\hline 1-octen-3-ol & $\mathrm{C}_{8} \mathrm{H}_{16} \mathrm{O}$ & 128 & $1.5 \pm 0.2^{\mathrm{a}}$ & $0.7 \pm 0.1^{\mathrm{b}}$ & $0.3 \pm 0.1^{\mathrm{c}}$ & $\begin{array}{c}\text { Sweet, } \\
\text { mushroom, } \\
\text { greasy }\end{array}$ \\
\hline 2,3-Dihydro-3,5-dihydroxy-6-methyl-4-pyranone & $\mathrm{C}_{6} \mathrm{H}_{8} \mathrm{O}_{4}$ & 144 & $1.7 \pm 0.1^{\mathrm{c}}$ & $4.3 \pm 0.4^{\mathrm{b}}$ & $7.6 \pm 0.5^{\mathrm{a}}$ & \\
\hline
\end{tabular}

"_" means that the compound was not detected because its content was too low.

Values are means \pm standard deviations of triplicate determinations.

Means in the same row with different letters are significantly different $(P<0.05)$ according to Duncan's multiple range test. Sample 1: unbaked walnut oil; Sample 2: oil of baked walnut without additive; Sample 3: oil of baked walnut with sucrose. 
with sucrose were more abundant than those in the oil from baked walnuts without additives. It should be noted that the baking with sucrose and salt technique was not considered here, because the addition of salt has no effect on the change in the volatile substances content. Through a comprehensive comparison of the aroma components of walnut oil obtained with different baking methods, it was found that the unbaked walnut oil had the aroma of fresh nuts, and those of baked walnut oils had a characteristic baked nut smell. In addition, the caramel flavor of the oil of baked walnuts with sucrose was stronger than the oil of the baked walnut without additives.

\section{CONCLUSIONS}

This study optimized three different baking techniques through sensory evaluation. By analyzing AV, PV and IP, it was concluded that the oil quality of the studied walnuts was significantly influenced by the baking method, especially given that the IP of the walnut oil increased from 6 to 17 $\mathrm{h}$ after baking, which indicated that the oxidative stability improved and the oil can be preserved for a longer time. The relative content in pyrazines with a baked nutty flavor increased after baking. Therefore, compared to the walnut oil obtained without baking, oils with special aroma can be obtained by the baking techniques studied herein. In addition, some aldehydes were produced through a caramelization reaction during baking with sucrose, and walnut oil had the strongest aroma after baking for $20 \mathrm{~min}$ with sucrose at $153^{\circ} \mathrm{C}$. Finally, the small differences in fatty acid composition observed before and after baking guarantee healthy amounts which are beneficial to the human body.

\section{ACKNOWLEDGEMENT}

The authors thank the Yunnan Jiye Biology Co., Ltd. for the financial support and for providing various walnut samples for this research.

\section{REFERENCES}

Abbey M, Noakes M, Belling GB, Nestel PJ. 1994. Partial replacement of saturated fatty acids with almonds or walnuts lowers total plasma cholesterol and low-density-lipoprotein cholesterol. Am. J. Clin. Nutr. 59, 995-999. https://doi.org/10.1093/ajen/59.5.995
Alamprese C, Ratti S, Rossi M. 2009. Effects of roasting conditions on hazelnut characteristics in a two-step process. J. Food Eng. 95, 272-279. https://doi.org/10.1016/j.jfoodeng. 2009.05.001

Amaral JS, Susana C, Seabra RM, Oliveira BPP. 2006. Effects of roasting on hazelnut lipids. $J$. Agric. Food Chem. 54, 1315-1321. https://doi. org $/ 10.1021 / \mathrm{jf0} 52287 \mathrm{v}$

AOCS. 2007. Official methods and recommended practices of the American Oil Chemists' Society. 5th edition, Urbana, IL, USA.

Aoyama T, Nakakita Y, Nakagawa M, Sakai H. 1982. Screening for antioxidants of microbial [filamentous fungi] origin. Agric. Biol. Chem. https://doi.org/10.1080/00021369.1982.10865439

Branch AL, Worthington RE, Roth IL, Chinnan MS, Nakayama TOM. 1987. Effect of Hot Water Immersion on Storage Stability of NonRefrigerated Peanuts 1. Peanut Sci. 14, 26-30. https://doi.org/10.3146/i0095-3679-14-1-7

Burdack-Freitag A, Schieberle P. 2010. Changes in the Key Odorants of Italian Hazelnuts (Coryllus avellana L. Var. Tonda Romana) Induced by Roasting. J. Agric. Food Chem. 58, 6351-6359. https://doi.org/10.1021/jf100692k

Fu M, Qu Q, Yang X, Zhang X. 2016. Effect of intermittent oven drying on lipid oxidation, fatty acids composition and antioxidant activities of walnut. LWT-Food Sci. Technol. 65, 1126-1132. https://doi.org/10.1016/j.lwt.2015.10.002

Garbe LA, Würtz A, Piechotta CT, Tressl R. 2010. The peptide-catalyzed Maillard reaction: characterization of $13 \mathrm{C}$ reductones. Ann. Ny. Acad. Sci. 1126, $244-$ 247. https://doi.org/ 10.1196/annals. 1433.046

Gunn BF, Aradhya M, Salick JM, Miller AJ, Yongping Y, Lin L, Xian H. 2010. Genetic variation in walnuts (Juglans regia and $J$. sigillata; Juglandaceae): Species distinctions, human impacts, and the conservation of agrobiodiversity in Yunnan, China. Am. J. Bot. 97, 660-671. https://doi.org/10.3732/ajb.0900114 Hao YB, Wang KJ, Wang SL, Zhuang YL. 2002. Analysis of the composition of protein and fatty acid in several early walnut nuts. Food Sci. 23, 123-125. https://doi. org/10.3321/j.issn:1002-6630.2002.10.033

Hodge JE. 1953. Dehydrated foods. Chemistry of browning reactions in model systems. J. Agric. Food Chem. 1, 625-651. https://doi.org/10.1021/ jf60015a004 
Mao XY, Hua YF, Chen GG. 2014. Amino Acid Composition, Molecular Weight Distribution and Gel Electrophoresis of Walnut (Juglans regia L.) Proteins and Protein Fractionations. Int. J. Mol. Sci. 15, 2003-2014. https://doi.org/10.3390/ ijms 15022003

Martins SIFS, Jongen WMF, Boekel MAJSV. 2000. A review of Maillard reaction in food and implications to kinetic modelling. Trends Food. Sci. Tech. 11, 364-373. https://doi.org/ 10.1016/ s0924-2244(01)00022-x

Olajide TM, Pasdar H, Weng, XC. 2018. A novel antioxidant: 6,6'-(butane-1,1-diyl) bis (4-methylbenzene-1,2-diol). Grasas Aceites 69 (3), e269. https://doi.org/10.3989/gya.0344181

Olajide TM, Liu T, Liu HA, Weng XC. 2020. Antioxidant properties of two novel lipophilic derivatives of hydroxytyrosol. Food Chem. 315, 126197. https:// doi.org/10.1016/j.foodchem.2020.126197

Rabrenovic B, Dimic E, Maksimovic M, Sobajic S, Gajickrstajic L. 2011. Determination of fatty acid and tocopherol compositions and the oxidative stability of walnut (Juglans regia L.) cultivars grown in Serbia. Czech. J. Food Sci. 29, 74-78. https://doi.org/10.2217/ cer.14.74

Santos J, Alvarez-Ortí M, Sena-Moreno E, Rabadán A, Pardo JE, Oliveira MBPP. 2017. Effect of Roasting Conditions on the Composition and Antioxidant Properties of Defatted Walnut Flour. J. Sci. Food Agric. 98, 1813-1820. https://doi. org $/ 10.1002 /$ jsfa. 8657

Szetao KWC, Sathe SK. 2000. Walnuts (Juglans regia L): proximate composition, protein solubility, protein amino acid composition and protein in vitro digestibility. J. Sci. Food Agric. 80, 1393-1401. https://doi.org/10.1002/10970010(200007)80:93.0.CO;2-F

Vaidya B, Eun JB. 2013. Effect of roasting on oxidative and tocopherol stability of walnut oil during storage in the dark. Eur. J. Lipid Sci. Tech. 115, 348-355. https://doi.org/10.1002/ ejlt.201200288

Verardo V, Riciputi Y, Sorrenti G, Ornaghi P, Marangoni B, Caboni MF. 2013. Effect of nitrogen fertilisation rates on the content of fatty acids, sterols, tocopherols and phenolic compounds, and on the oxidative stability of walnuts. LWT-Food Sci. Tech. 50, 732-738. https://doi.org/10.1016/j. lwt.2012.07.018

Wang W, Wang H, Chen W, Rong R. 2015. Effects of Different Drying Methods on Quality of Walnuts and Stability of Unsaturated Fatty Acids. J. Food Sci. Technol. 33, 59-65. https://doi.org/10.3969/j. issn.2095-6002.2015.01.011

Zhang J, Pan X, Mu Q, Xi C, Wang Z, Yuan S. 2012. Research about the Baking Process of 'Lvling No.1' Thin Shelled Walnut. Chinese Agric. Sci. Bulletin. 28, 237-240. https://doi.org/10.3969/j. issn.1000-6850.2012.06.044

Zhao JJ, Zhang RG, Ma YJ. 2014. Optimization of Protein Extraction from Walnut Dregs. Food Sci. 35, 18-19. https://doi.org/10.7506/spkx10026630-201418008

Ziaolhagh SH. 2017. Roasting Process Optimization of Walnut Kernels for the Preparation of Walnut Cream Using Response Surface Methodology. J. Nuts. 8, 31-40. https://doi.org/10.22034/ JON.2017.530390 